\title{
VukaniBantuTsohangBatho - Spirituality of black liberation: In memory of Vuyani Shadrack Vellem
}

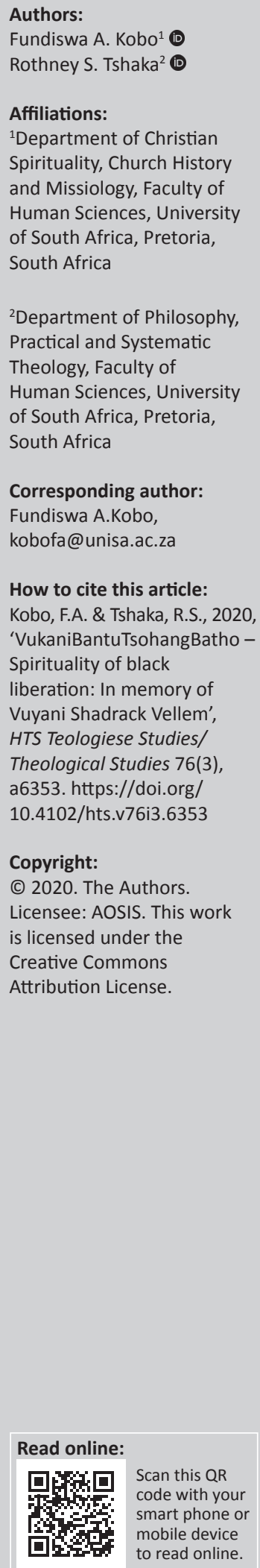

The untimely death of Professor Vuyani Vellem has left a devastating void in the circles of Black Theology of Liberation (BTL). His sharp mind and great acumen in spaces still controlled mostly by whites, namely the Academe, Church and Society, will be solely missed. Yet, knowing the activism of this giant of black scholarship and community activism, it would be remiss of us not to allow this deep sadness to act as a catalyst for associating with his perennial yearning of service to the marginalised black people of this world. It is this spirit that has been galvanising us into continuing with this fight for asserting the total humanity of those black people who continue to be treated as secondary members of society.

Vellem, more than any of his peers, boldly identified white supremacy as the single greatest threat to this country and to the world. Not only did he recognise the physical manifestation of white supremacy but also he understood very well that this white supremacy is underpinned by a perverted spirituality that keeps it intact. It is for this reason that he conceptualised VukaniBantuTsohangBatho as a historical project of black liberation whose vision is to invest in spirituality for liberation. This was to be a vehicle that awakens black people to the matrices of white supremacy and its functioning, especially in a country that is the result of a negotiated settlement.

Vuyani Vellem has, for the past 2 years or so, been preoccupied with the continuation of recycling of black bodies. He traced this from Elmina Castle, the Transatlantic slavery, which signifies the historical epoch of black pain. He looked at the genealogy of resistance launched at that time by slaves themselves. Even so, he felt that something continues to arrest the logic of resistance. And the question for him was, what is it that causes us as blacks to fail even when we attempt to be resilient. That for him was a starting point for VukaniBantuTsohangBatho, a movement whose aim is to invest in Spiritual Capital for the spiritual liberation of black African people in particular and humanity in general.

He felt that the School of Black Theology of Liberation (BTL) and the School of Black Consciousness (BC) have adequately analysed racism, the colonial matrix of power, and have denounced epistemologies, but they seem to struggle still. His analysis was that at a philosophical level, a lot has been done, and so, he began to propose that we look at faith, religiosity and spirituality. He felt that the philosophy of the West hides the spirit that sustains the superiority of this race, just as the inferiority of the black people is sustained by faith and spirit. So, what one believes is fundamental, he argued. His emphasis was bringing together ideology and faith for the comprehensive liberation of black humanity.

Contributions that are made in his memory are thus made of individual scholars whose paths converged as a result of the mutual interest of theology, church and society. These are reminders of a bold Vellem, who continually challenged hegemony. Not only was he sharp in insisting that the lived experiences of black people ought to frame the questions that guide the discourses for bettering and empowering themselves but also Vellem was a scholar who walked his talk. His praxis is evidenced in his involvement during the \#FeesMustFall, \#RhodesMustFall movements, where he was centrally located in the struggle and rallied alongside students against hegemony.

In response to the implicit suggestion by others on the irrelevance of BTL in a now politically liberated South Africa, Vellem pointed us to the question of the relevance of BTL as pervasive in the last two decades. A question that continues to be posed even in academic platforms, while exponents of the school continue to be at work reasserting, rearticulating and redefining the basics of the school simultaneously with parasitic fraudsters co-opting the elements of this paradigm without ceasing. He exposed one of the most troubling and vexing paradoxes of our times as the

Note: Special Collection entitled VukaniBantuTsohangBatho - Spirituality of Black Liberation, sub-edited by Fundiswa Kobo (UNISA) and Rothney Tshaka (UNISA). 
need by the erstwhile oppressor for the exponent of liberation to perpetuate and further the ends of marginalisation, exclusion and violence, albeit with sophistication and complexity today. Furthermore, is the need by BTL to respond to a number of theological innovations some of which have been paraded as successor paradigms to liberation.

He suggested the probability of sporadic collaboration between black men and women to deeply question what BTL itself identified as a triple oppression of women. This collaboration and even serious engagement between womanist discourses and BTL in responding to the perennial constructs of violence against women and ultimately the advancement of the school to respond to questions of human sexuality can surely be viewed as adequate in our times, he argued. In addition, violence against women, children and sexual minorities post 1994 is psychotic with litanies of selfdirected anger amongst the black people, the interlocutors of BTL itself, Vellem argued. 